\title{
Preliminary Study of Pesticide Drift into the Maya Mountain Protected Areas of Belize
}

\author{
Kristine Kaiser
}

Received: 4 August 2010/ Accepted: 29 November 2010/Published online: 14 December 2010

(C) The Author(s) 2010. This article is published with open access at Springerlink.com

\begin{abstract}
In Belize, Central America, many farms surrounding the Protected Areas of the Maya Mountains rely heavily on the application of agrochemicals. The purpose of this study was to test whether orographic drift of glyphosate and organophosphates into the nearby Maya Mountain Protected Areas occurred by collecting phytotelmic water from seven sites over 3 years. Regardless of location within the Maya Mountain Protected Areas, glyphosate was present; organophosphates were more common at ridge sites. Although glyphosate concentrations were low, due to the number of threatened species and the human use of stream water outside the Maya Mountain Protected Areas, better understanding of these effects is warranted.
\end{abstract}

Keywords Glyphosate · Organophosphates ·

Orographic precipitation

Globally, the use of pesticides and herbicides has become commonplace. Chemicals are often applied by spray (e.g., from backpacks or airplanes), where aerosol can be dispersed by wind or overspray can runoff into aquatic ecosystems. The use of these chemicals and their overspray has given rise to a multitude of studies of the toxicological

\section{K. Kaiser $(\bowtie)$}

Department of Ecology and Evolutionary Biology,

University of California Los Angeles, Los Angeles,

CA 90095-1606, USA

e-mail: kristinekaiser@gmail.com

Present Address:

K. Kaiser

Department of Biology, University of California,

Riverside, 900 University Dr., Riverside, CA 92521, USA effects of pesticides on non-target species, as well as the impact of pesticide drift into freshwater ecosystems (reviewed by Relyea and Hoverman 2006).

In Belize, Central America, land use is not homogenous in its distribution: in the north, extensive sugar cane and a variety of other food crops are grown (Fig. 1). Further south, surrounding the protected areas of the Maya Mountains, agricultural land is heavily planted with bananas and citrus. In all regions, application of agrochemicals to crops is common. The Maya Mountain Protected Areas occupy over $447,000 \mathrm{ha}^{2}$, and contain a diversity of habitats, including lowland moist rainforest, moist forest and cloud forest, and hold an abundance of endangered species, including several species of mammals, reptiles, and amphibians (IUCN 2010). Because montane cloud forests near agricultural areas have a propensity to accumulate chemicals used on nearby crops (Daly et al. 2007), it is of prime importance to determine the type and amount of pesticide drift reaching the Maya Mountain Protected Areas.

The purpose of this study was to test the hypothesis that pesticides applied to areas surrounding the Maya Mountain Protected Areas of Belize would be carried into the protected areas, maximally impacting regions immediately bordered by agricultural lands and cloud forests on the eastern edge of the Maya Mountains. If this were the case, orographic precipitation would cause the majority of toxicants to fall on the outer ridges of the Maya Mountains, and the central plateau would be relatively less impacted by agrochemicals from regions surrounding protected areas.

\section{Materials and Methods}

A total of seven sites across the protected areas of the Maya Mountains were sampled during June-August, 2006-2007 


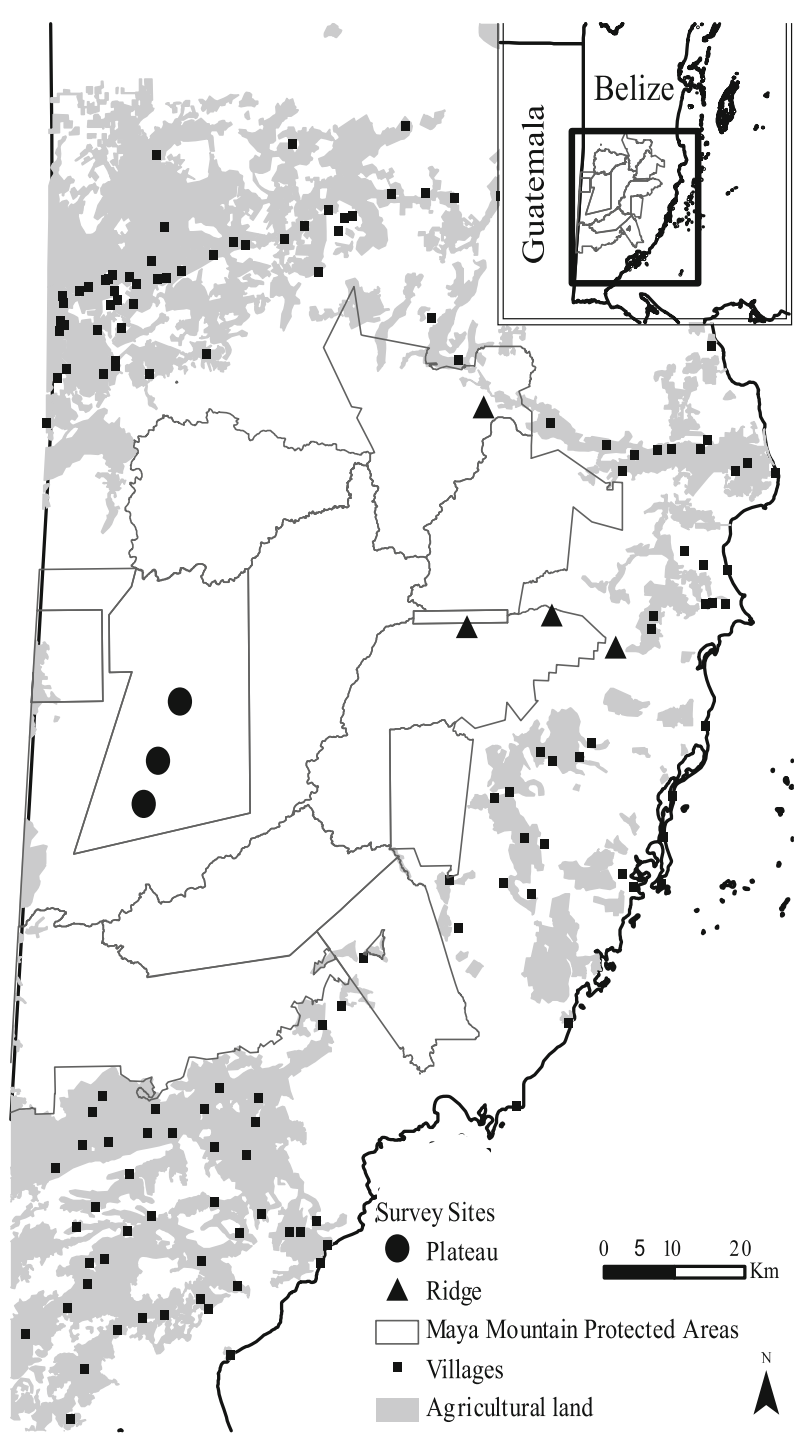

Fig. 1 Land use and survey sites in Belize. Shaded areas show the agricultural land in Belize, relative to Maya Mountain Protected Areas. Spatial data for this figure were acquired from the Biodiversity and Environmental Resource Data System of Belize (BERDS). Inset: Location of Belize in Central America

(Fig. 1), the rainiest months of the year in this region. Based on self-reported use of agrochemicals (Banana Growers Association, pers. comm.) and Citrus Growers Association (Nunny et al. 2001), glyphosate and common organophosphates and carbamate (OP/C) tests were implemented.

Water was collected from phytotelms (plant-held water) in new, sterile glass scintillation vials with poly-cone tops and immediately placed in a container with instant ice packs (water and ammonium nitrate; Dynarex) to exclude light. Icepacks were replaced hourly until samples could be frozen. Samples were frozen within $24 \mathrm{~h}$ of collection and were kept frozen until analysis, except during transport back to the United States. Five samples were collected per site per year, but due to breakage of some vials from some sites, only 33 samples were analyzed (Table 1). All samples were divided and analyzed separately using chemicalspecific test kits (Abraxis Kits, Warminster, PA). The range of sensitivities of each kit varied (Table 2). Although OP and $\mathrm{C}$ are not in the same chemical families, the screening test for these chemicals works similarly: it is a quantitative assay that measures inihibition of acetylcholinesterase. Inhibited acetylcholinesterase activity decreases the enzyme's ability to hydrolyze its substrate, acetylthiocholine, which in turn reacts with 5, 5'-dithio-bis(2-nitrobenzoic acid (DTNB), producing a yellow color. Reduced or absent color formation thus indicates presence of $\mathrm{OP} / \mathrm{C}$ in a sample.

All tests were conducted according to kit instructions, and using the provided reagents. Briefly, for OP/C tests, $100 \mu \mathrm{L}$ of sample were incubated at approximately $20^{\circ} \mathrm{C}$ for $5 \mathrm{~min}$ with oxider, neutralized, incubated for $30 \mathrm{~min}$ at $20^{\circ} \mathrm{C}$ with lyophilized actylcholinesterase. Acetylthiocholine and 5,5'-Dithio-bis(2-Nitrobenzoic Acid) were then added, and the reaction stopped. For glyphosate tests, $50 \mu \mathrm{L}$ of anti-glyphosate antibody was combined with $50 \mu \mathrm{L}$ of sample and incubated for $30 \mathrm{~min} ; 50 \mu \mathrm{L}$ of enzyme conjugate solution was then added and samples incubated for a further $60 \mathrm{~min}$. Sample wells were then washed, and $150 \mu \mathrm{L}$ of color solution added to wells. After 30 min of incubation, the reaction was stopped. For both $\mathrm{OP} / \mathrm{C}$ and glyphosate, absorbance at $450 \mathrm{~nm}$ was read immediately after stopping reactions. No attempt to concentrate samples was made.

Glyphosate ELISA reaction gave absolute quantification; the OP/C kit tested for presence of any chemical in this family. Samples for all tests were run in duplicate. Statistical analysis was carried out using StataIC 10.0 (StataCorp, College Station, TX).

\section{Results and Discussion}

Glyphosate was detected at all sites sampled (Table 1). Organophosphates/carbamate were detected at all sites, but the non-specificity of the kit makes it impossible to determine either the specific chemical present in the sample or its absolute concentration (Table 1). Glyphosate values in one sample from one site tested above the maximum quantifiable concentration of the kit $(5 \mu \mathrm{g} / \mathrm{L})$. A conservative estimate of $5 \mu \mathrm{g} / \mathrm{L}$ was used for statistical purposes; the duplicate of this sample tested within the range of the test kit. For samples which tested positive in duplicate, the average of the two concentrations for all statistical tests was used. For samples which tested positive only once, only the single value was used. 
Table 1 Results of glyphosate and OP/C tests

\begin{tabular}{lllll}
\hline Site & Plateau/ridge & $\mathrm{N}^{\mathrm{a}}$ & $\begin{array}{l}\text { Mean [glyphosate] } \\
(\mu \mathrm{g} / \mathrm{L})^{\mathrm{b}}\end{array}$ & $\begin{array}{l}\mathrm{N} \text { positive } \\
\text { OP/C }\end{array}$ \\
\hline Chiquibul & Plateau & 3 & 0.5929 & 0 \\
Las Cuevas & Plateau & 3 & 0.6018 & 0 \\
Mount Margaret & Ridge & 3 & $1.708^{\mathrm{c}}$ & 3 \\
Natural arch & Plateau & 2 & 0.2210 & 0 \\
Outlier & Ridge & 8 & 0.5088 & 3 \\
Tiger fern & Ridge & 7 & 0.7250 & 3 \\
Victoria Peak & Ridge & 7 & 0.6213 & 5 \\
\hline
\end{tabular}

${ }^{a}$ Each sample was run in duplicate

b Indicated are the mean glyphosate concentration of positive samples for each site. See text for details on calculation of concentration

${ }^{c}$ Concentration likely underestimates value. One sample tested above the maximum sensitivity $(5 \mu \mathrm{g} / \mathrm{L})$ of the test kit for glyphosate. For calculation of mean concentration, this sample was estimated as $5 \mu \mathrm{g} / \mathrm{L}$

Table 2 Range of sensitivity of organophospate/carbamate kit

\begin{tabular}{lll}
\hline Chemical $^{\mathrm{a}}$ & $\begin{array}{l}\text { Minimum } \\
\text { sensitivity }(\mu \mathrm{g} / \mathrm{L})\end{array}$ & $\begin{array}{l}\text { Maximum } \\
\text { sensitivity }(\mu \mathrm{g} / \mathrm{L})\end{array}$ \\
\hline Aldicarb & 10 & N/A \\
Azinphos methyl & 0.8 & N/A \\
Carbaryl & 160 & N/A \\
Carbofuran & 1.2 & N/A \\
Chlorpyrifos methyl & 1.3 & N/A \\
Chlorpyrifos ethyl & 1.0 & N/A \\
Diazinon & 1.0 & N/A \\
Dichlorvos & 0.5 & N/A \\
Dicrotophos & 20 & N/A \\
Disulfoton & 25 & N/A \\
Ethion & 3.9 & N/A \\
Malathion & 1.4 & N/A \\
Parathion & 1.0 & N/A \\
Phorate & 4.0 & N/A \\
Phosmet & 0.7 & N/A
\end{tabular}

${ }^{a} \mathrm{OP} / \mathrm{C}$ kit is non-specific, but tests for presence of various chemicals in this family

All plateau samples were taken in 2007, but ridge samples spanned the rainy seasons of 2006-2007. No significant differences were detected in concentration of glyphosate $(\mathrm{t}=-1.3224, \mathrm{df}=48, p=0.192)$, proportion of samples positive for glyphosate $\left(\mathrm{z}=-0.2340, \mathrm{n}_{1}=30, \mathrm{n}_{2}=20\right.$, $p=0.815) \quad$ or $\mathrm{OP} / \mathrm{C} \quad\left(\mathrm{z}=1.416, \quad \mathrm{n}_{1}=28, \mathrm{n}_{2}=20\right.$, $p=0.157)$ among years. Samples were then pooled to compare Vaca Plateau and ridge sites. Sites on the Vaca Plateau did not have a significantly different concentration of glyphosate than did sites along the eastern ridges of the protected areas $(\mathrm{t}=0.26, \mathrm{df}=64, p=0.800 ;$ Fig. 1$)$. The proportion of positive glyphosate samples at the ridge versus plateau sites did not differ $\left(\mathrm{z}=-0.7660, \mathrm{n}_{1}=50, \mathrm{n}_{2}=16\right.$, $p=0.444)$. Sites did differ in proportion positive for organophosphates, with no plateau samples testing positive for these chemicals $\left(\mathrm{z}=3.698, \mathrm{n}_{1}=48, \mathrm{n}_{2}=16\right.$, $p=0.0002$ ).

The observed differences in pesticide distribution can be interpreted in several different ways. The organophosphate/ carbamate test is non-specific, and the minimum sensitivity for various chemicals varies widely (Table 1). It is possible that the $\mathrm{OP} / \mathrm{C}$ present in plateau samples are simply present at concentrations lower than the ridge samples, and below the sensitivity of the test. Another explanation is that the detected OP/C were used not in commercial agricultural areas, but in villages surrounding protected areas, either on crops or as mosquito prophylaxis. OP/C pesticides have varying stability and half-life in water (Evert 2002; Newhart 2006; Xu 2000). Differences in samples may simply reflect differences in time since application of pesticides: glyphosate may simply have been applied more recently than was OP/C. Furthermore, glyphosate is stable to photodegradation (EPA 1993), while this is not the case for all organophosphates (e.g., Wolfe et al. 1978); care was taken to protect samples from light after collection, but it was impossible to control for the time between the most recent rainfall and the sample collection, as no weather data exist for these sites.

The ecological impact of such low concentrations of glyphosate being carried into protected areas is unclear. Studies have shown that glyphosate exhibits low toxicity to fish and aquatic invertebrates (Folmar et al. 1979; Giesy et al. 2000; Neškovi et al. 1996), but the effects of glyphosate vary widely based on formulation (Mann and Bidwell 1999; Tsui and Chu 2003). Although some preparations contain surfactants that significantly depress the LC50, requiring these products to be labeled as toxic to fish (EPA 1993), even these decreased toxic levels are in the $1.4-18 \mathrm{mg} / \mathrm{kg}$ range $\left(\mathrm{LC} 50_{24 \mathrm{~h}}\right)$, and thus above the levels 
found in this study (Folmar et al. 1979). However, there is growing evidence that sublethal concentrations of pesticides may affect a variety of behavioral and physiological responses (reviewed in Weis et al. 2001).

Also important to consider is the downstream effect of pesticide drift. Only a subset of the commonly used chemicals were tested. In Belize, municipal water exists only in portions of the country, and at least part of the population gets its drinking water from stream water coming from the Maya Mountain Protected Areas (Aimpun and Hshieh 2004). People in surrounding villages also use streams for bathing, swimming, and watering livestock. Thus, a monitoring program for stream water in the communities surrounding the farms near the protected areas would allow researchers to determine the safety of such water.

The results of this study suggest that pesticide drift is occurring, with no difference among years in sample detection. The effect of this drift on the fauna of the Maya Mountain Protected Areas is unknown, but a greater understanding of how species respond to pesticides may be one of the most pressing conservation questions, as well as how these residues affect pesticide concentrations downriver at the level of villages, where water may be used by humans.

Acknowledgments D.P. Janos and D. Kremples provided equipment for analyses. Funding was provided by the Columbus Zoo and Aquarium and the Critical Ecosystems Partnership Fund. Wildtracks provided infrastructure. P. Edgar, N. Mora, and E. Garcia provided field assistance. P.M. Narins and an anonymous reviewer provided helpful feedback on an earlier version of the manuscript.

Open Access This article is distributed under the terms of the Creative Commons Attribution Noncommercial License which permits any noncommercial use, distribution, and reproduction in any medium, provided the original author(s) and source are credited.

\section{References}

Aimpun P, Hshieh P (2004) Survey for intestinal parasites in Belize, Central America. Southeast Asian J Trop Med Public Health 35:506-511
Daly GL, Lei YD, Teixeira C, Muir DCG, Castillo LE, Wania F (2007) Accumulation of current-use pesticides in neotropical montane forests. Environ Sci Technol 41:1118-1123

EPA (1993) Reregistration eligibility decision document: Glyphosate; EPA-738-R-93-015. U.S. Environmental Protection Agency Office of Pesticide Programs, Washington

Evert S (2002) Environmental fate of Carbofuran. California Environmental Protection Agency, Department of Pesticide Regulation, Sacramento

Folmar L, Sanders H, Julin A (1979) Toxicity of the herbicide glyphosate and several of its formulations to fish and aquatic invertebrates. Arch Environ Toxicol Contam 8:269-278

Giesy J, Dobson S, Solomon K (2000) Ecotoxicological risk assessment for Roundup ${ }^{\circledR}$ herbicide. Rev Environ Contam Toxicol 167:35-120

IUCN (2010) IUCN Red List of threatened species. Version 2010.2. Available http://www.iucnredlist.org/. Accessed 2 Aug 2010

Mann R, Bidwell J (1999) The toxicity of glyphosate and several glyphosate formulations to four species of southwestern Australian frogs. Arch Environ Toxicol Contam 36:193-199

Neškovi N, Poleksi V, Elezovi I, Karan V, Budimir M (1996) Biochemical and histopathological effects of glyphosate on carp, Cyprinus carpio L. Bull Environ Contam Toxicol 56:295-302

Newhart KL (2006) Environmental fate of malathion. California Environmental Protection Agency Department of Pesticide Regulation, Sacramento

Nunny R, Santana M, Stone P, Tillet D, Walling D (2001) An investigation of the impact on reef environments of changing land-use in the Stann Creek District of Belize. The Watershed Reef Interconnectivity Scientific Study (WRIScS) 1997-2000

Relyea R, Hoverman J (2006) Assessing the ecology in ecotoxicology: a review and synthesis in freshwater systems. Ecol Lett 9:1157-1171

Tsui M, Chu L (2003) Aquatic toxicity of glyphosate-based formulations: comparison between different organisms and the effects of environmental factors. Chemosphere 52:1189-1197

Weis JS, Smith G, Zhou T, Santiago-Bass C, Weis P (2001) Effects of contaminants on behavior: biochemical mechanisms and ecological consequences. Bioscience 51:209-217

Wolfe N, Zepp R, Paris D (1978) Carbaryl, propham and chlorpropham: a comparison of the rates of hydrolysis and photolysis with the rate of biolysis. Water Res 12:565-571

Xu S (2000) Environmental fate of carbaryl. California Environmental Protection Agency, Department of Pesticide Regulation, Sacramento 